\title{
Production Of Biocomposite Packaging Materials From Fruit Juice Processing Wastes
}

\section{Seda ERSUS ${ }^{1}$, Arzu YALÇIN MELİKOĞLU ${ }^{*}$, Serap CESUR ${ }^{2}$}

\begin{abstract}
The use of biocomposite packaging materials is nowadays considered as an important issue for overcoming the environmental problems caused by plastic-based packaging materials that is produced from fossil fuels which take centuries to degrade in nature. Biocomposite materials are made up of two components, a polymer matrix and a natural organic reinforcing agent/filling material. In the production of biocomposites, the use of low-cost and widely available waste materials have advantages such as increasing biodegradability and a reduction in weight of the more expensive materials. The pomace resulting from the large quantities of peel, seed, stalks, etc. produced as waste by the fruit juice processing sector, and the polysaccharides such as starch, pectin, cellulose, hemicellulose and lignin derived from this pomace, has the potential to be used as reinforcing agent and/or filling material in the development of biocomposite packaging materials with $10-50 \%(\mathrm{w} / \mathrm{w})$ addition. In this review, (i) extraction of some of the biopolymers such as pectin and cellulose from the fruit juice processing waste, (ii) production of biocomposite food packaging materials, and (iii) investigation of the effects of reinforcing agents obtained from the fruit juice processing waste on the mechanical, barrier and biodegradation properties of biocomposite materials were summarized.
\end{abstract}

Keywords: Fruit juice waste, pomace, pectin, cellulose, biocomposite film

\section{Meyve Suyu İşleme Tesisi Atıklarından Biyokompozit Ambalaj Malzemelerinin Üretimi}

ÖZET: Günümüzde fosil kaynaklardan elde edilen, doğada kendiliğinden yok olması yüzlerce yıl alan plastik esaslı ambalaj atıklarının neden olduğu çevresel sorunların giderilmesinde, biyobozunur özellik gösteren biyokompozit ambalaj malzemelerinin kullanımı önemli bir alternatiftir. Biyokompozit malzeme polimer matris ve doğal organik takviye ajanı/dolgu maddesi olmak üzere iki bileşenden meydana gelmektedir. Özellikle biyokompozit malzemelerin üretiminde, ucuz ve bol olan atıkların kullanımı; maliyet avantajı, biyobozunma davranışı ve daha pahalı malzeme ağırlığında azalma sağlamaktadır. Meyve suyu işleme sanayinde atık olarak yüksek miktarda ortaya çıkan kabuk, çekirdek, sap vb. bileşenleri içeren posanın kendisi ve bu atıklardan elde edilen nişasta, pektin, selüloz, hemiselüloz ve lignin gibi polisakkaritler biyokompozit ambalaj malzemelerinin geliştirilmesinde takviye ajanı ve/veya dolgu maddesi olarak ağırlıkça \%10-50 oranında kullanım potansiyeline sahiptir. Bu derlemede; (i) meyve suyu üretim atıklarında bulunan pektin ve selüloz biyopolimerlerinin üretimi (ii) biyokompozit gıda ambalaj malzemelerinin üretimi, (iii) meyve suyu işletim tesisi atıklarından elde edilen takviye ajanlarının biyokompozit malzemenin mekanik, bariyer ve biyobozunma davranışı üzerine etkileri konusunda bilgi verilmektedir.

Anahtar kelimeler: Meyve suyu atığg, posa, pektin, selüloz, biyokompozit film

\footnotetext{
${ }^{1}$ Seda ERSUS (Orcid ID: 0000-0003-0475-4099), Arzu YALÇIN MELİKOĞLU (Orcid ID: 0000-0002-2762-4169), Ege Üniversitesi, Mühendislik Fakültesi, Gıda Mühendisliği Bölümü, İzmir, Türkiye

${ }^{2}$ Serap CESUR (Orcid ID: 0000-0001-6581-0854), Ege Üniversitesi, Mühendislik Fakültesi, Kimya Mühendisliği Bölümü, İzmir, Türkiye

*Sorumlu Yazar/Corresponding Author: Arzu YALÇIN MELIKKOĞLU, e-mail: arzuyalcin@gmail.com
}

Geliş tarihi / Received: 19-02-2019

Kabul tarihi / Accepted: 08-10-2019 


\section{INTRODUCTION}

Agriculture and agricultural-based industries occupy a relatively important place in Turkey's economy and economic development. Turkey, which produces 16.3 million tons of fruit annually, is in the $6^{\text {th }}$ place in the world, and also accounting for $3 \%$ of total fruit production worldwide (Akdağ, 2011). A large part of the fruit mainly apple, peach, apricot, orange and sour cherry produced in Turkey is processed into juice. The production and processing of pomegranate, tomato, carrot and grape also have an increasing trend recently (Akdağ, 2011; Anonymous, 2011; Aygören et al., 2014).

Solid waste produced during the processing of fruit juice, comprising peel, seed and stalks, etc. is called pomace, and the quantity of pomace produced by different fruit can vary between $20-50 \%$ w/w. While $25-35 \%$ of the input material becomes waste in apple juice production, this ratio is $50 \%$ in orange juice production and 20\% in grape juice production (Oreopoulou and Tzia, 2007; Djilas et al., 2009; Van et al., 2013). These wastes are generally used as animal feed (Massias et al., 2015). However, it is known that fruit pomace is rich in phenolic compounds and has antioxidant, antiallergic, antiviral and antimicrobial properties (Llorch et al., 2002; Barreca et al., 2014; Denev et al., 2014; Bupesh et al., 2016; Karling et al., 2017; Alison and Simmons, 2018). The extract obtained from these wastes has the potential to be used in the food, cosmetic and pharmaceutical sectors. The current global trend towards the efficient use of natural resources is also supporting sustainable agricultural production and the transformation of agricultural waste into high value added products. In the last 10 years, it has seen increased momentum in studies focusing on the extraction of such natural polymers as pectin and cellulose (Pinheiro et al., 2008; Fishman and Cooke; 2009; Azad et al., 2014; Wang et al., 2016; Szymanska-Chargot et al., 2017). The pomace itself and the biopolymers such as pectin and cellulose that can be obtained from this pomace all have the potential to be used in the development of biocomposite packaging materials. Actually, carrot and apple pomace are rich in cellulose and contain 51.6 and $43.6 \%$ cellulose of the dietary fiber (DF) proportion, respectively, while pear pomace contains more pectin $(13.4 \%)$ than apple pomace $(11.7 \%)$ (Table 1$)$.

Table 1. Proportions of dietary fibers in fruit pomaces (Nawirska and Kwasniewska, 2005)

\begin{tabular}{lcccc}
\hline Pomace & Pectin (\%) & Hemicellulose (\%) & Cellulose (\%) & Lignin (\%) \\
\hline Apple & 11.7 & 24.4 & 43.6 & 20.4 \\
Cherry & 1.51 & 10.7 & 18.4 & 69.4 \\
Chokeberry & 7.85 & 33.5 & 34.6 & 24.1 \\
Black currant & 2.73 & 25.3 & 12.0 & 59.3 \\
Pear & 13.4 & 18.6 & 34.5 & 33.5 \\
Carrot & 3.88 & 12.3 & 51.6 & 32.2 \\
\hline
\end{tabular}

Cellulose and pectin are the most widespread polysaccharide biopolymers in nature and can be obtained from plant sources. Biopolymers, which are environmentally-friendly and renewable polymers can in contrast to synthetic plastics, be biologically degraded by microorganisms such as fungi and bacteria, and be eliminated within a short period in nature by being converted into $\mathrm{CO}_{2}, \mathrm{H}_{2} \mathrm{O}$ and biomass products (Aruchelvi et al., 2007; Melikoğlu Yalçın et al., 2017). However, biodegradable materials produced from natural polymers have some disadvantages such as lower gas barrier and mechanical properties when compared to synthetic plastics. They also cause some difficulties in processing through traditional production techniques, which limits their usage in the food packaging 
industry. But, the production of biocomposites through the modification of synthetic polymers with natural polymers allows for an improvement of the material's mechanical, resistance and barrier properties, while also encouraging biodegradability of the synthetic plastics (Mangiacapra et al., 2006; Okelo et al., 2012; Sumigin et al., 2012; Aigbodion et al., 2013; Gaikwat et al., 2016; Baron et al., 2017; Batori et al., 2017; Ali et al., 2017).

\section{Extraction of Plant-Based Biopolymers from The Waste of Fruit Juice Processing}

\section{Pectin}

Pectin is a natural polysaccharide that is found in the cell walls of plant tissue, between cells and in the central lamella region. Pectin is found in many fruit and vegetables, holding cells together and providing structural resistance. They are constituted of long and linear chain polysaccharides formed by an $\alpha-1,4$ bond between D-galacturonic acid units (Cemeroğlu, 2004; Zhang et al., 2013). With its film forming properties, pectin is a polysaccharide that is widely used in the food sector as a thickener, renewable film and coating material, and also in the pharmaceutical sector as a coating and capsule material. The most commonly used raw materials for commercial pectin production are the white layer named albedo in citrus fruit and the pomace and peel of apples. The quality of pectin is closely related to the properties of the raw material used. Pectin production is generally based on extraction techniques and drying of the produced pectin gel. In pectin production, granting solubility to the pectin found in the raw material requires treatment for a certain time and temperature in a dilute acid solution, followed by the filtration, precipitation, washing, drying of the extract and grinding steps (Figure 1) (Arslan, 1994; Garna et al., 2007; Baississe et al., 2010; Günkaya et al., 2016).

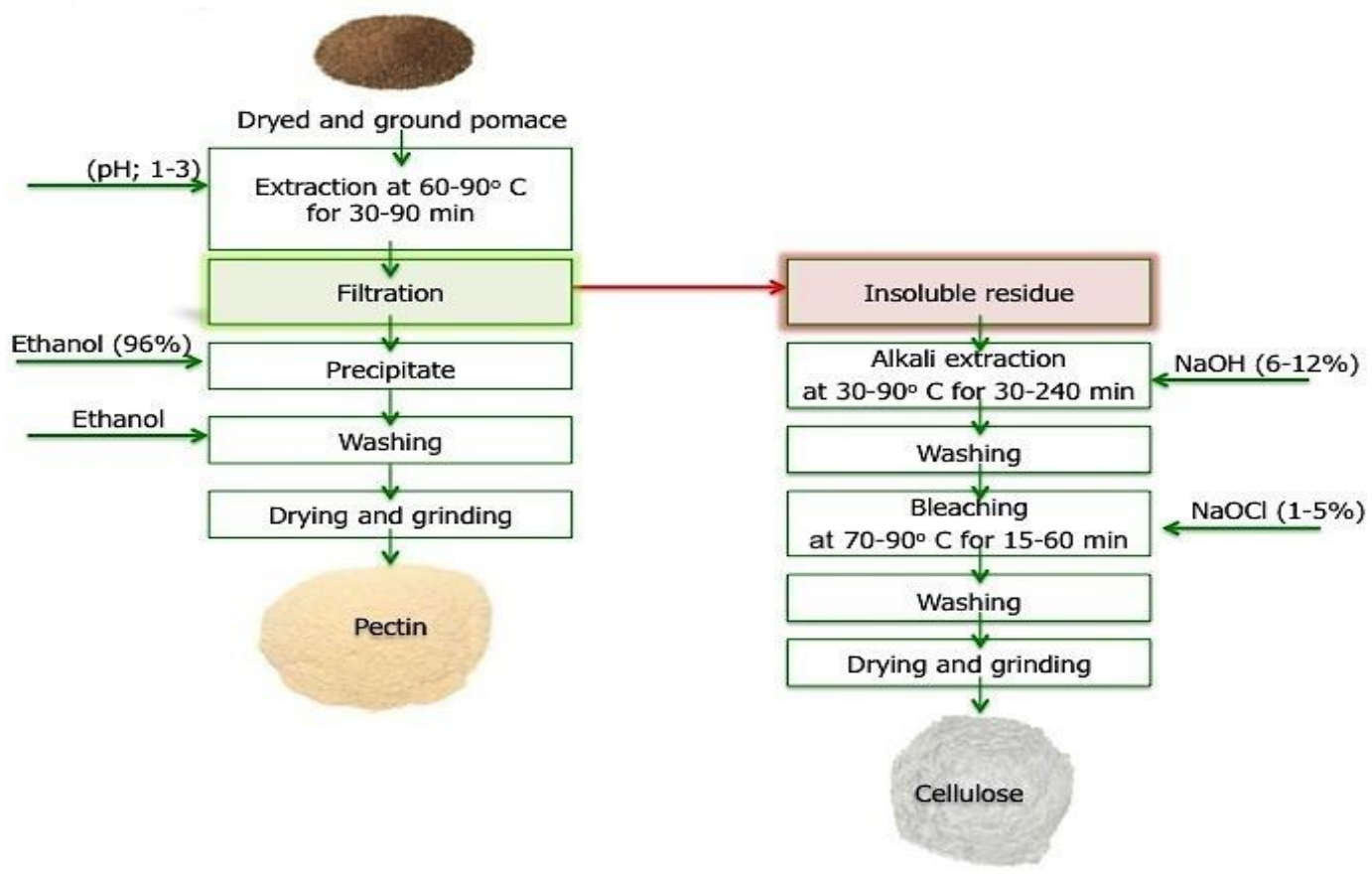

Figure 1. Pectin and cellulose extraction from plant-based materials (Baron et al., 2017; Günkaya et al., 2016; Garna et al., 2007; Szymanska-Chargot et al., 2017; Rodsamran and Sothornvit, 2015)

During the extraction of pectin from the peel and pomace of fruit such as apples, oranges, carrots, pomegranate and grapes that are used in fruit juice production, the $\mathrm{pH}$ value, extraction time, 
temperature and the acid used in the extraction step are important factors for improving the yield and the capacity of the pectin to form a gel. In general, high pectin yield depending on the type of the fruit can be achieved at low pH values and high extraction temperature and time (Miceli-Garcia, 2014; Kar and Aslan, 1999). Depending on the degree of esterification of the carboxyl groups on the pectin molecules, pectins are classified as either high methoxyl or low methoxyl. Low methoxyl pectins with less than $50 \%$ esterification exhibit gelling in the presence of calcium, while high methoxyl pectins with more than $50 \%$ esterification exhibit gelling in environment with acid and sugars (Sharma et al., 2006).

Scabio et al. (2007) determined a pectin yield of $9.05 \mathrm{~g} 100 \mathrm{~g}^{-1}$ dry pomace and with an esterification degree of $74.39 \%$, resulting in a high methoxyl pectin in a pectin extraction carried out via a 20 min treatment in an $50 \mathrm{mM} \mathrm{HNO}_{3}$ solution at $80{ }^{\circ} \mathrm{C}$ from apple pomace. Twari et al. (2017), investigated the effect of $\mathrm{pH}$ value on pectin yield and the degree of esterification during pectin extraction from sun dried orange peel. Extraction in a citric acid solution with a $\mathrm{pH}$ value ranged between 1 and 2.5 caused different extraction yields where the samples treated with lower $\mathrm{pH}$ values $(\mathrm{pH}=1)$ provided a higher yield pectin extraction. In another study, carrot pomace treated for 30$150 \mathrm{~min}$ at a $\mathrm{pH}$ value of $0.5-2.5$ and a temperature of $50-90{ }^{\circ} \mathrm{C}$ resulted in a pectin yield ranged from 5 to $15.2 \%$, while the degree of pectin esterification was found as low methoxyl pectin $(22.1-51.8 \%)$ (Jafari et al., 2016).

\section{Cellulose}

Cellulose is the most widely found biopolymer in plant world and is a fundamental component of the plant cell wall. Together with hemicellulose and lignin, cellulose are found in the cell walls of woody plants and are referred collectively as lignocellulosic substances. Cellulose is a linear homopolymer composed of D-glucopyranose units linked with $\beta$-1,4-glycosidic bonds. It has a lowcost, high resistant, high thermal resistance and it is environmentally-friendly polymer that can be effectively broken down by many microorganisms (Sampath et al., 2016; Johar et al., 2012; Anwar et al., 2014).

The extraction of cellulose from plant tissue is performed through an extraction system consisting of series of consecutive steps such as (i) pre-treatment, (ii) removal of pectin, (iii) removal of hemicellulose and lignin through alkali treatment, and also (iv) removal of remaining lignin through bleaching, resulting in pure cellulose (Figure 1) (Szymanska-Chargot et al., 2017; Rodsamran and Sothornvit 2015). In literature dealing with the extraction of cellulose from carrot, tomato, cucumber and apple pomace, the cellulose yields were reported as $10.01 \pm 0.20,8.6 \pm 0.34,16.13 \pm 0.90$

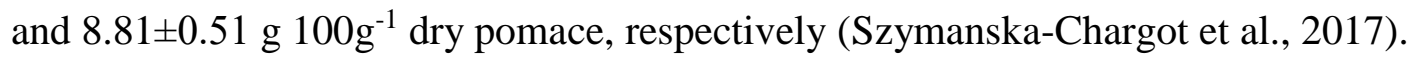

\section{Biocomposite Packaging Materials}

Packaging, which is the widely used in the food industry, is a coordinated system with a multidisciplinary structure that allows the product to be protected, preserved, stored and transported until it reaches the consumer, and also enables it to be sold and to communicate with the consumer. In fact, the delivery to consumers of such rapidly spoiling foods such as meat, milk, fruit and vegetables is made possible through the protective and storage function of packages with other food processes (Kocamanlar, 2009; Arıkan, 2010).

The selection of packaging materials for foods involves the consideration of parameters such as (i) the respiration rate of the fresh food (fruits and vegetables), (ii) the planned shelf life, (iii) the oxygen and water vapor permeability of the packaging material, (iv) mechanical properties and (v) 
cost. In this context, synthetic plastics obtained from petroleum derivative fossil fuels such as PE, PP, PVC, PET, PS etc. are widely preferred in the packaging of food materials, owing largely to their (i) inertness, (ii) resistance to microorganisms, (iii) ability to act as a barrier to gases, (iv) ease of shaping/molding and their ability to retain shape for long periods, and (v) low cost. However, after completing their service life, plastic-based packages form significant amounts of waste that lead to environmental and economic problems (Mangaraj et al., 2009; Shin and Selke, 2014; Lima et al., 2018). Furthermore, the selection process for suitable packaging materials according to respiration rate and the quality characteristics of the food materials generally lead to the preparation of polymers with different matrices and many layered combinations of these, which in turn limits the recyclability of these materials. Efforts to resolve the environmental problems caused by plastic-based packaging waste, which have today reached global proportions, has given momentum to studies aimed at producing biocomposite packaging materials with biodegradable properties.

The goal of producing biocomposites is to enhance the mechanical, resistance and barrier properties of the material, while also encouraging its biodegradability. Hence, it becomes necessary to take into account some factors such as the appropriate matrix and reinforcing agent, the production technique, and the resistance properties of the components. Organic reinforcing agents are described as environmentally friendly owing to their renewability, biodegradability and ability to ensure energy resaving when burned. Furthermore, by combining the positive features of natural materials and the synthetic polymers that compose them, biocomposites have the potential to provide even more positive results. In the development of such high added value products as biocomposite packaging materials can be obtained from agricultural waste represent a cost advantage, biodegradability and a reduction in the weight of the more expensive material (Ali et al., 2017; Makhijani et al., 2015; Aigbodion et al., 2013; Thakur et al., 2010). Encouraging biodegradability to polymers through the addition of organic additives and/or filling materials is important because it (i) helps to reduce the environmental pollution caused by the packaging wastes that do not degrade in nature, (ii) allows the design of packaging materials that does not pose a threat to food safety, (iii) provides a solution for the disposal of the agricultural waste by opening up a new area of use with high added value, and (iv) contributes to sustainable development.

The production of biocomposite packaging materials is performed mainly through two methods, being the solvent casting and the extrusion techniques. The solvent casting technique is based on the principle of (i) dissolving the polymer in a suitable solvent, (ii) adding a natural organic reinforcing agent/filling material, plasticizing, cross-linking, gelling etc. additives to the solution, (iii) casting the solution on the fixed surface and (iv) removing the solvent to obtain a film (Siemann, 2005). The extrusion technique, on the other hand, is based on the principle of first transferring the polymeric material and addition of natural organic reinforcing agent/filling material to the feeding unit of a single or twin screw extrusion machine, after which it is turned into a molten state under a certain pressure and temperature (Tadmor and Gogos, 2006). The extrusion technique is preferred by the packaging industry for the industrial level production and in the manufacturing of plastic based packaging materials. The extrusion process maintains homogenous distribution of the film thickness with the rapid and serial production and has the ability to produce film to the desired dimensions and the preparation of the film surface for pressure through corona application; and its economizing on workforce needs through automation. Figure 2 shows a production diagram of biocomposite packaging materials through the extrusion technique. 
Production Of Biocomposite Packaging Materials From Fruit Juice Processing Wastes

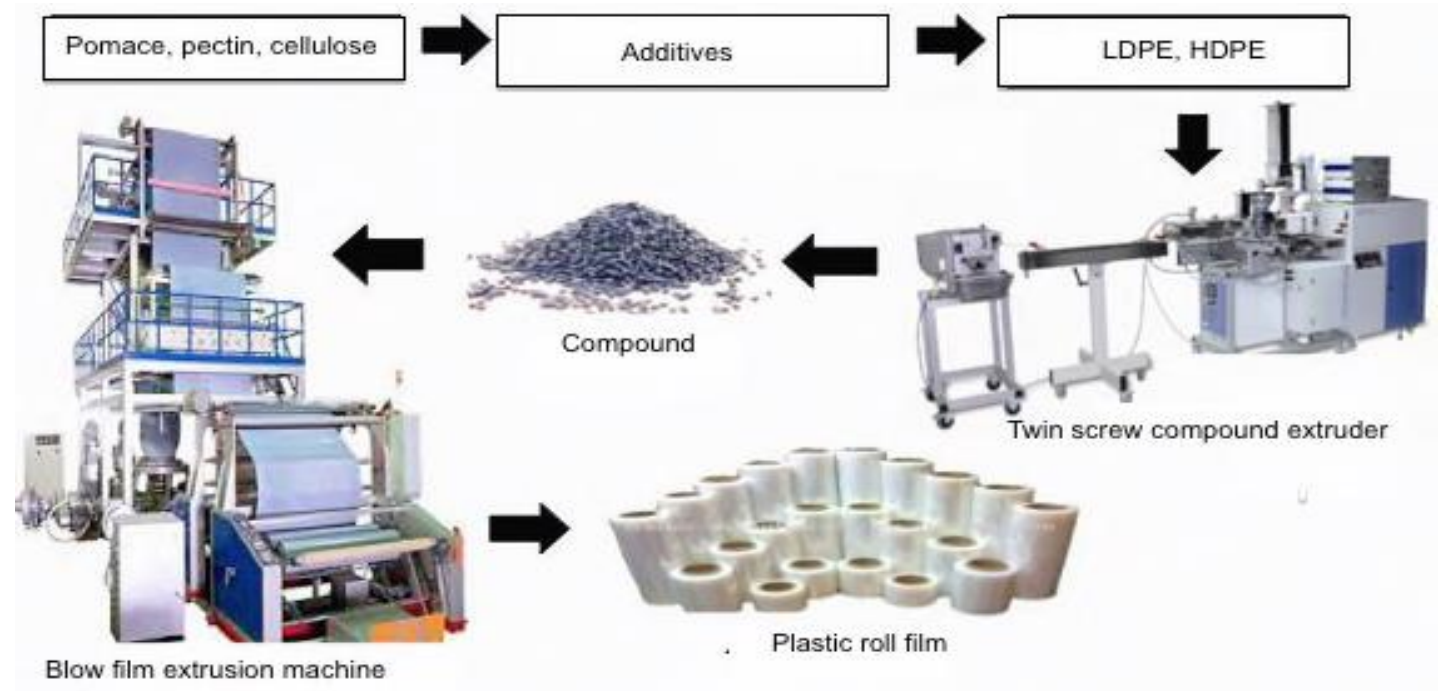

Figure 2. The biocomposite packaging material production by the extrusion technique

During the extrusion process, various additives, such as plasticizers, compatibilizers and crosslinking agents are used to ensure the homogenous distribution of organic filling substances within the polymer matrix. In fact, to improve the processability of organic filling materials that cannot readily mix with non-water-based systems due to their strong hydrogen bonds and polarity, various additives are used, such as maleic anhydride, dicumyl peroxide, polyethylene glycol (PEG) and glycerol (Aimin and Chao, 2003; Yang et al., 2007; Bengtsson et al., 2007).

\section{Attributes of Biocomposite Packaging Materials}

Studies have determined that the usage of dried ingredients from the wastes of fruit juice processing has great potential in biocomposite material production. The pomace and the extracted biopolymers such as pectin and cellulose from it can be used to produce biocomposite packaging materials. These biomaterials affect the barrier and mechanical properties where encourages the biodegradability and active properties of the synthetic plastics (Okelo et al., 2012; Sumigin et al., 2012; Aigbodion et al., 2013; Gaikwat et al., 2016; Baron et al., 2017; Batori et al., 2017; Ali et al., 2017).

Gaikwad et al. (2016) produced biocomposite films containing PVA and apple pomace powder (AP) $(1,5,10,30 \%)$ by solvent casting technique, and investigated the mechanical, gas barrier and active properties of the biocomposite product. It was found that an increase in apple pomace concentration led to an increase in the oxygen permeability of the biocomposite material, along with a decrease in its tensile strength. Also despite to apple pomace's high phenolic content $\left(12.3 \mathrm{mg} \mathrm{GAE} \mathrm{g}^{-1}\right.$ dry weight) and antioxidant activity (DPPH scavenging activity of 70\%), it was fairly effective in granting the resulting biocomposite material with antioxidant properties where the antioxidant activity increased with increasing concentration of apple pomace in biocomposite matrix. In a PVA/AP biocomposite material containing 30\% apple pomace, the total quantity of phenolic substances and the DPPH scavenging activity were determined as $7.9 \mathrm{mg} \mathrm{GAE} \mathrm{g}^{-1}$ dry weight and $39.8 \%$, respectively. For investigating the thermal properties of LDPE/cellulose materials, Sumigin et al. (2012) was used twin screw extruder for production of a biocomposite containing commercial cellulose at ratios of 2, 5 and $10 \%$. The increase in cellulose concentrations in biocomposite materials did not change the melting temperature $\left(\mathrm{T}_{\mathrm{m}}\right)$ of the LDPE/cellulose composite, while its crystallization peak were found to be $61-62,98{ }^{\circ} \mathrm{C}$ and melting peak at $110-111^{\circ} \mathrm{C}$. The crystallization of the biocomposite material is decreased according to LDPE. 
Baron et al. (2017) is also isolated pectin from orange peel and blended it with chitosan in different concentrations to form a biocomposite by solvent casting technique. Glycerol was used as plasticizing agent in the production of the biopolymeric material. The increase in the concentration of pectin had showed an effect on the moisture and water solubility of the packaging film significantly $(\mathrm{P}<0.05)$. It was also determined that the increase in pectin concentration in chitosan and pectin blend decreased the tensile strength of the material (MPa), while increased its elongation at break (\%).

Batori et al. (2017) studied the mechanical properties of a biofilm obtained from orange-peel waste by solvent casting technique, and determined that the tensile strength (MPa) of the biofilm was close to that of synthetic plastics (LDPE, HDPE, PP), while its elongation (\%) was relatively lower then synthetic plastics. In another study, orange peel waste was added to a HDPE matrix as a reinforcing agent at ratios of $5-25 \%(\mathrm{w} / \mathrm{w})$ to form a biocomposite material. The researchers determined that the tensile and bending strengths of biocomposite materials were increased with the increase in orange peel concentration (Aigbodion et al., 2013).

Ali et al. (2017) blended cellulose fibers obtained from pineapple peel with LDPE in a twin screw extruder to obtain a biocomposite material, the biodegradability of the material were measured by burying the material in garden soil for 6 months. The researchers reported that a concentrationdependent loss of weight occurred in samples containing 30-50\% pineapple peel fibers, which they attributed to the consumption and breaking-down of polymer chains by soil microorganisms. In another biodegradability study of biocomposite materials prepared HDPE/cellulose $(\% 5-20 \mathrm{w} / \mathrm{w})$ blends were kept in soil for 182 days under controlled conditions $\left(25-27^{\circ} \mathrm{C}, 60-70 \% \mathrm{RH}\right.$ and $\mathrm{pH} 6.4-$ 6.6) and after $100^{\text {th }}$ days, degradation rate is increased (Okelo, 2012).

\section{CONCLUSIONS}

Studies results have demonstrated the high potential usage of the fruit juice processing waste in the development of biocomposite packaging materials. It has been determined that the use of fruit juice waste as reinforcing agents is fairly effective in encouraging biodegradability of synthetic plastics, which normally take centuries to degrade in nature. Moreover, the biodegradation process depends on the concentration of the natural organic reinforcing agent/filling material in biocomposites. In the production of biocomposite materials, increasing the concentration of organic wastes has been shown negatively effect on the mechanical properties, where they lead to increase the oxygen permeability. The usage of the fruit juice processing wastes in the production of biocomposite packaging materials will not only enable the acquisition of high added value products from these wastes, but also have a potential to give active and biodegradable properties to synthetic plastics, and overcome the environmental and economic problems related to synthetic plastics. Due to the environmental problems caused by plastic-based packaging materials, many European countries has limitations to their use, while also enacting laws that promote the use of bio-based packaging materials with biodegradable properties. Hence, the usage of fruit juice processing wastes in the packaging industry will not only support the development of biodegradable and environmentally based packaging materials with bio-based content, but also help in fulfilling the legal requirements related to exports.

\section{ACKNOWLEDGMENT}

This study was demonstrated as oral presentation at the International Agriculture, Forest, Food Sciences and Technology Conference (ICAFOF, 15-17 May 2017, Cappadocia / Turkey). 


\section{REFERENCES}

Aigbodion VS, Atuanya CU, Igogori EA, Ihom P, 2013. Development of High-Density Polyethylene/Orange Peels Particulate Bio-Composite. Gazi University Journal of Science, 26 (1):107-117.

Akdağ E, 2011. Türkiye meyve suyu vb. ürünler sanayi raporu. Meyve Suyu Endüstrisi Derneği (MEYED), İstanbul.

Aimin Z, Chao L, 2003. Short Communication Chemical Initiation Mechanism of Maleic Anhydride Grafted onto Styrene-butadiene-styrene Block Copolymer. European Polymer Journal, 39: 1291- 1295.

Ali RR, Rahman WA, Kasmaini RM, Ibrahim N, Hasbullah H, Sadikin AN, Asli UA, Abouzari E, 2017. Pineapple Peel Fibre Biocomposite: Characterisation and Biodegradation Studies. Chemical engineering transactions, 56: 1333-1338.

Allison BJ, Simmons CW, 2018. Obtaining Multiple Coproducts from Red Grape Pomace via Anthocyanin Extraction and Biogas Production. J. Agric. Food Chem., 66: 8045-8053.

Anonymous, 2011. Batı Akdeniz Kalkınma Ajansı, Meyve suyu sektör raporu http://baka.org.tr/uploads/1303486551MEYVE-SUYU-KATALOG--TURKCE-SON.pdf.__(Date of access: 15 February 2019).

Anwar Z, Gulfraz M, Irshad M, 2014. Agro-industrial lignocellulosic biomass a key tounlock the future bioenergy: A brief review. Journal of Radiation Research and Applied Sciences, 7: 163-173.

Arutchelvi J, Sudhakar M, Arkatkar A, Doble M, Bhaduri S, Uppare VP, 2007. Biodegradation of polyethylene and polypropylene. Indian Journal of Biotechnology, 7: 9- 22.

Arıkan A, 2010. Gıda ambalaj malzemeleri. Ambalaj Bülteni, Temmuz-Ağustos, 32-35.

Arslan N, 1994. Pektinin fizikokimyasal özellikleri, üretimi ve gıdalarda kullanımı. GIDA, 19(3): 187-192.

Aygören E, Sancak AZ, Akdağ E, Demirtaş M, Dönmez D, Sancak K, Demir A, 2014. Türkiye'de meyve suyu üretim sektörü. XI. Ulusal Tarım Ekonomisi Kongresi, 3-5 Eylül, Samsun.

Azad AKM, Ali MA, Akter S, Rahman D, Ahmed M, 2014. Isolation and characterization of pectin extracted from lemon pomace during ripening. Journal of Food and Nutrition Sciences, 2(2): 30-35.

Baississe S, Ghannem H, Fahloul D, Lekbir A, 2010. Comparison of Structure and Emulsifying Activity of Pectin Extracted from Apple Pomace and Apricot Pomace. World Journal of Dairy \& Food Sciences, $5(1)$.

Baron RC, Perez LL, Salcedo JM, Cordoba LP, Sobral PJA, 2017. Production and characterization of films based on blends of chitosan from blue crab (Callinectes sapidus) waste and pectin from Orange (Citrus sinensis Osbeck) peel. International Journal of Biological Macromolecules, 98: 676-683.

Batori V, Jabbari M, Akesson D, Lennartsson PR, Taherzadeh MJ, Zamani A, 2017. Production of PectinCellulose Biofilms: A New Approach for Citrus Waste Recycling. International Journal of Polymer Science, 9 p.

Barreca D, Bellocco E, Laganà G, Ginestra G, Bisignano C, 2014. Biochemical and antimicrobial activity of phloretin and its glycosilated derivatives present in apple and kumquat. Food Chem, 160: 292-297.

Bengtsson M, Le Bailiff M, Oksman K, 2007. Extrusion and Mechanical Properties of Highly Filled Cellulose Fibre- Polypropylene Composite. Applied Science and Manufacturing Composites, 38: 1922-1931.

Bupesh G, Vijaykumar TS, Manivannan S, Beerammal M, Manikandan M, 2016. Identification of Secondary Metabolites, Antimicrobial and Antioxidant Activity of Grape Fruit (Vitis vinifera) Skin Extract. Diabetes Obes Int. J., 1(1):1-6.

Cemeroğlu,, 2004. Meyve ve Sebze işleme Teknolojisi, Başkent Klişe Matbaacıllk, 670s, Ankara.

Denev P, Kratchanova M, Ciz M, Lojek A, Vasicek O, Nedelcheva P, 2014. Biological activities of selected polyphenol-rich fruits related to immunity and gastrointestinal health. Food Chem, 157: 37-44.

Djılas S, Čanadanović J, Ćetković BG, 2009. By-products of fruits processing as a source of phytochemicals. Chemical Industry \& Chemical Engineering Quarterly, 15(4): 191- 202.

Fishman ML, Cooke PH, 2009. The structure of high-methoxyl sugar acid gels of citrus pectin as determined by AFM. Carbohydrate Research, 344(14): 1792-1797. 
Gaikwad KK, Lee JY, Lee YS, 2016. Development of polyvinyl alcohol and apple pomace bio-composite film with antioxidant properties for active food packaging application. J. Food Sci. Technol., 53(3): 16081619.

Garna H, Mabon N, Robert C, Cornet C, Nott K, Legros H, Wathelet B, Paquot M, 2007. Effect of extraction conditions on the yield and purity of apple pomace pectin precipitated but not washed by alcohol. Journal of Food Science, 72:C1-C9.

Günkaya Z, Demirel R, Banar M, 2016. Portakal kabuğu atıklarından üretilen biyokompozit ambalaj filminin aflatoksinlere karşı etkisinin incelenmesi. Pamukkale Univ. Muh. Bilim Derg., 22(6): 513-519.

Jafari F, Khodaiyan F, Kiani H, Hosseini SS, 2016. Pectin from carrot pomace: Optimization of extraction and physicochemical properties. Carbohydrate Polymers, 157: 1315-1322.

Johar N, Ahmad I, Dufresne A, 2012. Extraction, preparation and characterization of cellulose fibres and nanocrystals from rice husk. Industrial Crops and Products, 37(1): 93-99.

Kocamanlar E., 2009. Ambalaj ve fonksiyonları. Ambalaj Bülteni, Eylül-Ekim, 2009.

Kar F, Arslan N, 1999. Characterization of Orange Peel Pectin and Effect of Sugars, L-ascorbic acid, Ammonium Persulfate, Salts on Viscosity of Orange Peel Pectin Solutions. Carbohydrate Polymers, 40: 285-291.

Karling M, Bicas TC, Lima VA, Oldoni TL, 2017. Grape and Apple Pomaces from Southern Brazil: Valorization of By-Products through Investigation of Their Antioxidant Potential. J. Braz. Chem. Soc., 28 (10):1857-1865.

Lee M, 2009. Solution-casting of Disulfonated Poly(arylene ether sulfone) Multiblock Copolymer Films for Proton Exchange Membranes. Dissertation submitted to the faculty of the Virginia Polytechnic Institute and State University in partial fulfillment of the requirements for the degree of Doctor of Philosophy thesis (Printed).

Lima EMB, L AM, Mungiata APS, Santos NRR, Preira ICS, Neves TTM, Gonçalves LFC, Moreira APD, Middea A, Neuman R, Tavares MIB, Oleveira RN, 2018. Poly(lactic acid) biocomposites with mango waste and organo-montmorillonite for packaging. Journal of Applied Polymer Science, 1-11.

Liu S, Yu T, Wu Y, Li W, Li B, 2014. Evolution of cellulose into flexible conductive green electronics: A smart strategy to fabricate sustainable electrodes for supercapacitors. RSC Advances, 4(64): 34134-34143.

Llorch R, Espin JC, Tomas-Barberan FA, Ferreres F, 2002. Artichoke (Cynara scolymus L.) Byproducts as a Potential Source of Health-Promoting Antioxidant Phenolics. J. Agric. Food Chem., 50: 3458-3464.

Makhijani K, Kumar R, Sharma S, 2015. Biodegradability of Blended Polymers: A Comparison of Various Properties. Critical Reviews in Environmental Science and Technology, 45:1801-1825.

Mangaraj S, Goswami TK, Mahajan PV, 2009. Applications of Plastic Films for Modified Atmosphere Packaging of Fruits and Vegetables: A Review. Food Eng Rev., 1:133-158.

Mangiacapra P, Gorrasi G, Sorrentino A, Vittoria V, 2006. Biodegradable nanocomposites obtained by ball milling of pectin and montmorillonites. Carbohydrate Polymers, 64: 516 - 523.

Massias A, Boisard S, Baccaunaud M, Calderon FL, Subra-Paternault P, 2015. Recovery of phenolics from apple peels using $\mathrm{CO}_{2}+$ ethanol extraction: kinetics and antioxidant activity of extracts. J Supercrit Fluids, 98:172-182.

Melikoğlu Yalçın A, Aytaş BE, Cesur S, Bilek S, 2017. Poliolefinlerin bozunma, biyobozunma mekanizmaları ve çevresel etkileri. Çevre Bilim ve Teknolojisi 2(1): 1-25.

Miceli-Garcia LG, 2014. Pectin from apple pomace: extraction, characterization, and utilization in encapsulating alpha-tocopherol acetate,. University of Nebraska - Lincoln, Food Science and Technology Department, Master Thesis(Printed).

Nawirska A, Kwasniewska M, 2005. Dietary fibre fractions from fruit and vegetable processing waste. Food Chem., 91: 221-225.

Okelo AP, 2012. Mechanical, thermal, diffusion and degradation properties of high density polyethylene and cellulose blends. Kenyatta University, Master of science Thesis(Prnted). 
Oreopoulou V, Tzia C, 2007. Utilization of plant by-products for the recovery of proteins, dietary fibers, antioxidants, and colorants, In V. Oreopoulou, \& W. Russ (Eds.), Utilization of by-products and treatment of waste in the food industry., Vol. 3. , pp. 209-232, New York.

Pinheiro ER, Silva MDA, Gonzaga LV, Amante ER, Amboni MMC, 2008. Optimization of Extraction of HighEster Pectin from Passion Fruit Peel (Passiflora edulis Flavicarpa) with Citric Acid by using Response Surface Methodology. Bioresourse Technology, 99: 5561-5566.

Ray SS, Okamoto M, 2003. Polymer/layered silicate nanocomposites: a review from preparation to processing. Progress in Polymer Science, 28: 1539-1641.

Rodsamran P, Sothornvit R, 2015. Renewable cellulose source: isolation and characterisation of cellulose from rice stubble residues. International Journal of Food Science and Technology, 50; 1953-1959.

Sampath UGTM, Ching YC; Chuah CH; Sabariah JJ; Lin PC, 2016. Fabrication of Porous Materials from Natural/Synthetic Biopolymers and Their Composites. Materials, 9: 991.

Scabio A, Fertonani HCR, Schemin MHC, Petkowicz CL, Carneiro EBB, Nogueira A, Wosiacki G, 2007. A Model for Pectin Extraction from Apple Pomace. Brazilian Jounal of Food Technology, 259-265.

Sharma BR, Naresh L, Dhuldhoya NC, Merchant SU, Merchant UC, 2006. An overview on pectin. Times Food Processing Journal, 44-51.

Shin J, Selke SEM, 2014. Food packaging, Food Processing: Principles and Applications, Second Edition. Edited by Stephanie Clark, Stephanie Jung, and Buddhi Lamsal. (C) 2014 John Wiley \& Sons, Ltd. Published 2014 by John Wiley \& Sons, Ltd.

Siemann U, 2005. Solvent cast technology - a versatile tool for thin film production. Progr Colloid Polym Sci., 130: $1-14$.

Šumigin D, Tarasova E, Krumme A, Viikna A, 2012. Influence of cellulose content on thermal properties of poly(lactic) acid/cellulose and low-density polyethylene/cellulose composites. Proc. Est. Acad. Sci., 61(3): 237-244.

Szymanska-Chargot M, Chylinska M, Gdula K, Koziol A, Zdunek A, 2017. Isolation and Characterization of Cellulose from Different Fruit and Vegetable Pomaces. Polymers, 9(10): 2-16.

Tadmor Z, Gogos CG, 2006. Principles of Polymer Processing, Wiley-Interscience, New York.

Thakur VK, Singha AS, Mehta JK, 2010. Renewable resource based green polymer composite: analysis and charecterization. Int J. Anal Ch., 15(3): 137-146.

Twari AK, Saha SN, Yadav VP, Upadhyay UK, Katiyar D, Mishra T, 2017. Extraction and Characterization of Pectin from Orange Peels. International Journal of Biotechnology and Biochemistry, 13(1): 39-47.

Van JS, Gama R, Morrison D, Swart S, Pletschke BI, 2013. Food processing waste: problems, current management and prospects for utilisation of the lignocellulose component through enzyme synergistic degradation. Renew Sust Energ, 26: 521-531.

Wang X, Chen Q, Lü X, 2016. Pectin extracted from apple pomace and citrus peel by subcritical water. Food Hydrocolloids, 38: 129-137.

Yang HS, Kim HJ, Park HJ, Lee BJ, Hwang TS, 2007. Effect of compatibilizing agents on rice-husk flour reinforced polypropylene composites. Comp. Struct., 77: 45-55.

Zhang LF, Ye XQ, Ding T, Sun XY, Xu YT, Liu DH, 2013. Ultrasound effects on the degradation kinetics, structure and rheological properties of apple pectin. Ultrasonics Sonochemistry, 20: 222-231. 